\title{
The influence of habitat conditions on the performance of two invasive, annuals - Impatiens glandulifera and Bidens frondosa
}

\author{
Kinga Kostrakiewicz-GieratT ${ }^{1}$ \& Maria Zając $^{2}$ \\ ${ }^{1}$ Department of Plant Ecology, Institute of Botany, Jagiellonian University, Lubicz 46, PL-31-512 Kraków, Poland; e-mail: \\ kinga.kostrakiewicz@uj.edu.pl \\ ${ }^{2}$ Department of Plant Taxonomy, Phytogeography \& Herbarium, Kopernika 27, PL-31-501 Kraków, Poland
}

\begin{abstract}
The investigations of habitat conditions on the variability of selected population features in the two invasive, annuals with different life-history traits were conducted in the years 2008-2010, in the Polish part of the Carpathian Mountains in communities characterized by the gradual decrease of light availability. The individuals of Impatiens glandulifera were surveyed along roadsides, in willow thickets, as well as inside and along the edges of the riparian forest, whereas the individuals of Bidens frondosa were observed in riverside gravels characterized by a different species composition. Each year, the number and density of individuals (stems) occurring in the particular sites were examined, as well as the height and the fruit production in 30 randomly chosen stems were surveyed. Moreover, the number of seeds per fruit, the diaspore dimensions and the seedling recruitment in laboratory conditions were examined during each season. As the values of height of individuals, number of fruits per stem, number of seeds per fruit, as well as the seedling abundance in some groups were not consistent with the normal distribution and the variances were not homogeneous, the non-parametric Kruskal-Wallis test was used in statistical analyses.

Much greater number and density of individuals of Impatiens glandulifera were found in riparian forest, than in willow thickets and along the roadsides. In all sites the number and density of individuals increased steadily in consecutive seasons. The great number and density of Bidens frondosa individuals observed in shady and partly shady sites during the first year of studies raised in the second year and subsequently dramatically decreased in the third season. The lowest number and density of individuals noted in the first season in unshaded site raised substantially in subsequent years. The height of stems, as well as seed and fruit production of both taxa diminished with a decrease of height of neighboring plants. The seed dimensions presented the spatial and temporal variability, whereas the number of seedlings among consecutive years and in successive sites did not differ.

The considerable height of the individuals of Impatiens glandulifera, high production of large fruits and seeds in open and dry roadside areas can contribute to more effective ballistic dissemination, while substantial seedling recruitment enables the colonization of new, perhaps more advantageous sites. On the other hand, lower individual height, as well as fruit and seed production and considerable seedling emergence allow the population to last and to gradually extend the area in forest communities. The considerable abundance of the high-statured Bidens frondosa individuals, substantial production of large capitula and achenes contribute to long persistence of populations in open and sun-lit sites. The gradually decrease in the height of the stems, achene number and size observed in partly-shaded and shaded places might allow to long-distance dispersal of seeds by animals, while substantial seedling recruitment might contribute to establishment in new areas.
\end{abstract}

Key words: fruit production; seed production; seed size; seedling recruitment; stem length

\section{Introduction}

The invasion of non-native species, which has become more intense since the second half of the 20th century, continuously contributes to the elimination of native taxa, a decrease in the biodiversity of communities and degradation of numerous ecosystems worldwide (Pyšek \& Richardson 2010; Vilá et al. 2011). The studies of various aspects of the biology of invasive species populations make it possible to determine the possibility of the population's survival at the colonized site and the prospects for their further spread. The results of the research may form a basis for the development of more effective methods of elimination these species, thus improving the condition of some types of habitats (Sakai et al. 2001). So far, most attention has been devoted to the observations of invasive clonal plants. The main trends of research focused on the analysis of population dynamics and structure (Aule \& Brandl 1997), the influence of genet integration on the effectiveness of photosynthesis and biomass allocation (Wang et al. 2008 ), the trade-off between growth and reproduction (Brown \& Eckert 2005; Lambrecht-McDowell \& Radosevich 2005; Xiao et al. 2011), the effectiveness of

* Corresponding author 
asexeual and sexual propagation in different conditions (Dietz et al. 2002; Riis et al. 2010) and determination of the genetic variability level ( $\mathrm{Li}$ et al. 2006). Simultaneously it should be pointed out, that perennial nonclonal species have been examined to a lesser degree (e.g., Dietz \& Ullmann 1998; van Kleunen \& Johnson 2005; Pergl et. al. 2006). Research on annual invasive plants focuses on various sexual reproduction aspects, shaping the dynamics of the population. At present, the number of studies concerning flowering phenology (Suzuki et al. 2007), fruit and seed production (MolinaMontenegro et al. 2008; Rinella et al. 2010), propagule size (Fumanal et al. 2007) and seedling recruitment (Fumanal et al. 2008). Despite growing interest in the aforementioned issues, the present state of knowledge on numerous taxa remains unsatisfactory. In connection with this insufficient level of knowledge, it was attempted to examine the influence of habitat conditions on performance of Impatiens glandulifera Royle and Bidens frondosa $\mathrm{L}$. - the most invasive species in Europe (Lambdon et al. 2008), characterized by different life history traits. The specific aims concentrated on: (1) the evaluation of abundance of individuals in study sites, (2) the estimation of height of individuals, (3) the observation of fruit and seed production, (4) the examination of diaspore dimensions and seedling recruitment.

We hypothesized that:

- the abundance of Impatiens glandulifera and Bidens frondosa individuals differ among years and sites

- the stem height, fruit and seed production, diaspore dimensions and germination ability of Impatiens glandulifera and Bidens frondosa individuals do not differ significantly in consecutive years

- the height of stems of both species, fruit and seed production, as well as diaspore dimensions and seedling recruitment increase from open habitats, via mild-shaded places, to crowded and shaded sites.

\section{The studied species}

The Himalayan Balsam Impatiens glandulifera Royle is one of the tallest invasive species, which can reach up to 2-3 metres under favourable conditions. The stem, di-

Table 1. The characteristics of habitat conditions in studied Impatiens glandulifera L. localities in Polish Carpathians.

\begin{tabular}{|c|c|c|c|c|c|}
\hline $\begin{array}{l}\text { The popula- } \\
\text { tion locality }\end{array}$ & & Zembrzyce & & Szczawa & Podobin \\
\hline The habitat & Riparian forest & Riparian forest edge & Willow thickets & $\begin{array}{l}\text { Roadside area domi- } \\
\text { nated by herbs creat- } \\
\text { ing several branches } \\
\text { and wide leaves }\end{array}$ & $\begin{array}{l}\text { Roadside area domi- } \\
\text { nated by herbs form- } \\
\text { ing upright stems } \\
\text { and narrow leaves }\end{array}$ \\
\hline $\begin{array}{l}\text { The } \\
\text { coordinates }\end{array}$ & $\begin{array}{l}\text { N } 49^{\circ} 46^{\prime} 20.92^{\prime \prime} \\
\text { E } 19^{\circ} 35^{\prime} 40.38^{\prime \prime}\end{array}$ & $\begin{array}{l}\text { N } 49^{\circ} 46^{\prime} 19.83^{\prime \prime} \\
\text { E } 19^{\circ} 35^{\prime} 40.33^{\prime \prime}\end{array}$ & $\begin{array}{l}\mathrm{N} 49^{\circ} 45^{\prime} 54.1^{\prime \prime} \\
\mathrm{E} 19^{\circ} 35^{\prime} 46.9^{\prime \prime}\end{array}$ & $\begin{array}{l}\mathrm{N} 49^{\circ} 36^{\prime} 39.5^{\prime \prime} \\
\mathrm{E} 20^{\circ} 17^{\prime} 39.7^{\prime \prime}\end{array}$ & $\begin{array}{l}\text { N } 49^{\circ} 38^{\prime} 46.7^{\prime \prime} \\
\text { E } 20^{\circ} 04^{\prime} 33.8^{\prime \prime}\end{array}$ \\
\hline $\begin{array}{l}\text { The site area } \\
\left(\mathrm{m}^{2}\right)\end{array}$ & 70 & 75 & 60 & 50 & 60 \\
\hline $\begin{array}{l}\text { The species } \\
\text { number }\end{array}$ & 37 & 19 & 42 & 25 & 31 \\
\hline $\begin{array}{l}\text { The dominants } \\
\text { (species, with } \\
\text { cover exceed } \\
20 \% \text { ) }\end{array}$ & $\begin{array}{l}\text { Fraximus excelsior, } \\
\text { Padus avium, Al- } \\
\text { nus incana, Acer } \\
\text { negundo }\end{array}$ & $\begin{array}{l}\text { Alnus incana, } \\
\text { Robinia pseudacacia, } \\
\text { Euonymus europea }\end{array}$ & $\begin{array}{l}\text { Salix fragilis, Salix } \\
\text { triandra }\end{array}$ & $\begin{array}{l}\text { Impatiens parviflora, } \\
\text { Melilotus albus, } \\
\text { Chenopodium album }\end{array}$ & $\begin{array}{l}\text { Urtica dioica, Fes- } \\
\text { tuca pratensis, Tus- } \\
\text { silago farfara, }\end{array}$ \\
\hline $\begin{array}{l}\text { The subdomi- } \\
\text { nants (species, } \\
\text { with cover } \\
\text { achieved } 5- \\
20 \% \text { ) }\end{array}$ & $\begin{array}{l}\text { Cornus sanguinea, } \\
\text { Sambucus nigra, An- } \\
\text { thriscus silvestris, } \\
\text { Festuca giganthea, } \\
\text { Galium aparine, } \mathrm{Hu} \text { - } \\
\text { muls lupulus }\end{array}$ & $\begin{array}{l}\text { Acer negundo, } \\
\text { Sambucus nigra, } \\
\text { Sorbus aucuparia, } \\
\text { Rubus hirtus, Gal- } \\
\text { ium aparine, }\end{array}$ & $\begin{array}{l}\text { Armoracia rusti- } \\
\text { cana, } \\
\text { Erigeron canaden- } \\
\text { sis, Amaranthus } \\
\text { chlorostachys }\end{array}$ & $\begin{array}{l}\text { Artemisia vulgaris, } \\
\text { Erigeron annuus, } \\
\text { Mycelis muralis }\end{array}$ & $\begin{array}{l}\text { Aegopodium poda- } \\
\text { graria, Dactylis } \\
\text { glomerata, }\end{array}$ \\
\hline $\begin{array}{l}\text { The mean vas- } \\
\text { cular plant } \\
\text { height }(\mathrm{cm})\end{array}$ & 317.2 & 218.0 & 119.4 & 31.9 & 58.9 \\
\hline $\begin{array}{l}\text { The mean vas- } \\
\text { cular plant } \\
\text { cover }(\%)\end{array}$ & 85.0 & 95.0 & 80.0 & 85.0 & 95.0 \\
\hline $\begin{array}{l}\text { The mean } \\
\text { moss and } \\
\text { lichen cover } \\
(\%)\end{array}$ & 5.0 & 0.0 & 0.0 & 0.0 & 2.0 \\
\hline $\begin{array}{l}\text { The mean light } \\
\text { intensity }(\mathrm{lx})^{1}\end{array}$ & 5100.0 & 9000.0 & 15000.0 & 40000.0 & 4200.0 \\
\hline
\end{tabular}

${ }^{1}$ The value of statistical significance of differences among sites in light intensity, performed using the H Kruskal-Wallis test reached $44.85(\mathrm{df}=4, P<0.001)$. 
Table 2. The characteristics of habitat conditions in studied Bidens frondosa L. localities in Polish Carpathians

\begin{tabular}{|c|c|c|c|}
\hline The population locality & Żbikowice & Osieczany & Soboniowice \\
\hline The habitat & The shaded river gravel & $\begin{array}{l}\text { The partially shaded river } \\
\text { gravel }\end{array}$ & The unshaded river gravel \\
\hline The coordinates & $\begin{array}{l}\text { N } 49^{\circ} 44^{\prime} 50.73^{\prime \prime} \\
\text { E } 20^{\circ} 34^{\prime} 42.58^{\prime \prime}\end{array}$ & $\begin{array}{l}\text { N } 49^{\circ} 51^{\prime} 02.1^{\prime \prime} \\
\text { E } 19^{\circ} 59^{\prime} 09.4^{\prime \prime}\end{array}$ & $\begin{array}{l}\text { N } 49^{\circ} 59^{\prime} 23.94^{\prime \prime} \\
\text { E } 20^{\circ} 00^{\prime} 28.68^{\prime \prime}\end{array}$ \\
\hline The site area $\left(\mathrm{m}^{2}\right)$ & 80 & 86 & 100 \\
\hline The species number & 47 & 30 & 25 \\
\hline $\begin{array}{l}\text { The dominants (species, with } \\
\text { cover exceed } 20 \% \text { ) }\end{array}$ & $\begin{array}{l}\text { Solidago serotina, Tanacetum } \\
\text { vulgare, Salix viminalis }\end{array}$ & $\begin{array}{l}\text { Epilobium hirsutum, Solidago } \\
\text { serotina, Polygonum mite }\end{array}$ & $\begin{array}{l}\text { Polygonum mite, Atriplex } \\
\text { prostata, Chenopodium al- } \\
\text { bum, Urtica dioica }\end{array}$ \\
\hline $\begin{array}{l}\text { The subdominants (species, } \\
\text { with cover achieved } 5-20 \% \text { ) }\end{array}$ & $\begin{array}{l}\text { Artemisia vulgaris, Epilo- } \\
\text { bium hirsutum, Erigeron } \\
\text { canadensis, }\end{array}$ & $\begin{array}{l}\text { Tanacetum vulgare, Veron- } \\
\text { ica beccabunga, Phalaris } \\
\text { arundiacea }\end{array}$ & $\begin{array}{l}\text { Festuca pratensis, Tussilago } \\
\text { farfara, Rumex obtusifolius }\end{array}$ \\
\hline $\begin{array}{l}\text { The mean vascular plant } \\
\text { height }(\mathrm{cm})\end{array}$ & 110.6 & 74.0 & 24.0 \\
\hline $\begin{array}{l}\text { The mean vascular plant } \\
\text { cover }(\%)\end{array}$ & 65.0 & 80.0 & 85.0 \\
\hline $\begin{array}{l}\text { The mean plant moss and } \\
\text { lichen cover }(\%)\end{array}$ & 0.0 & 10.0 & 2.0 \\
\hline $\begin{array}{l}\text { The mean light intensity at } \\
\text { the soil level }(\mathrm{lx})^{1}\end{array}$ & 29000.0 & 35000.0 & 41000.0 \\
\hline
\end{tabular}

${ }^{1}$ The value of statistical significance of differences among sites in light intensity, performed using the H Kruskal-Wallis test reached $25.71(\mathrm{df}=2, P<0.001)$

vided into nodes and internodes, is thick and hollow. Lanceolate serrate leaves on the main stem grow in three-leaf whorls, while the leaves on side stems are arranged in an alternate manner. The shallow root system reaches a depth of 10 to $15 \mathrm{~cm}$. Large flowers, $2.5-4.0 \mathrm{~cm}$ long, have a dorsiventral symmetry, and they are pink, white or purple. Insect-pollinated flowers are borne on the umbel-shaped inflorescence. A club-shaped fleshy capsule $1.5-3.5 \mathrm{~cm}$ long and $0.5-1.5 \mathrm{~cm}$ wide containing on average 5 to 6 seeds in the fruit. Round and slightly flattened seeds, 4-7 mm long and 2-4 mm wide are ballochoric (Berling \& Perrins 1993). Seed dormancy can be broken by means of cold stratification, consisting in keeping the imbibed seeds at a temperature of $4^{\circ} \mathrm{C}$ for three months. Seed germination can also be accelerated by gibberellic acid and seed shell scarification (Fitter \& Peat 1994). Impatiens glandulifera is native to the humid-moist part of the subtropical climate zone at mountain areas with moderate monsoon effects. The individuals are thermofrequent but in direct sunlight they are rather rare. The plant grows in alluvial rainforests and clearings, at higher altitudes in tall herb fringe communities along mountain brooks, along dikes and borders of roads. The European range of Impatiens glandulifera covers temperate areas. It is most frequent along rivers and in flood plain vegetation, mostly in the willow bushes and alluvial willow-poplar forests, as well as in tall herb fringe communities (Balogh 2008).

Devil's Beggarticks Bidens frondosa L. is a tall plant reaching up to $160 \mathrm{~cm}$. They have green or purple stem branches at the upper or middle section. Anthodia consisting of numerous small, dark yellow, tubular flowers grow at the top of the stem and its branches. Seeds, dispersed by animals, have the form of flattened achenes with two barbs. The seeds are $5-10 \mathrm{~mm}$ long and $1.5-4 \mathrm{~mm}$ wide. They are characterised by high germination ability, and the development of seedlings is accelerated by keeping imbibed seeds at temperatures ranging from 20 to $35^{\circ} \mathrm{C}$ (Fitter \& Peat 1994; Moravcová et al. 2010). Bidens frondosa is a pioneer species of moist grounds; it colonises river banks, mud flats, ditches, ponds and other open alluvial habitats (Toussaint \& Bedouet 2005).

\section{Material and methods}

The research was conducted in the Polish part of the Carpathian Mountains in communities characterized by a different species composition. The investigations of Impatiens glandulifera individuals were carried out at five sites by roads occupied by herbs with different architecture, in willow thickets, as well as inside and along the edges of the riparian forest (Table 1). The observations of Bidens frondosa were conducted at three sites in river gravel yards in sun-lit site with limited flora abundance and with a prevalence of taxa with delicate, creeping shoots, in partly shaded site with low species diversity with a high participation of high perennial plants, as well as in a shady place with high species diversity predominated by high perennial plants and shrubs (Table 2). In the year 2008 all study sites were bordered, while their area were measured. Subsequently, the average height of vascular plants was evaluated on the basis of measurements of 20 randomly chosen stems of different species performed using a folding tape measure. The estimation of the vascular plant cover, as well as moss and lichen cover were performed from $3^{\text {rd }}$ to $11^{\text {th }}$ of August 2008. Altogether, 50 measurements per site were taken using the aluminum frame $(30 \mathrm{~cm} \times 30 \mathrm{~cm})$ in randomly chosen sites. Each time, the percent of ground surface covered by vascular plants/moss and lichens within the frame were estimated. 
Table 3. The abundance and density of individuals of Impatiens glandulifera Royle in the studied localities in the years $2008-2010$.

\begin{tabular}{|c|c|c|c|c|}
\hline Population locality & Habitat & Year & The total number of individuals & The number of individuals per $\mathrm{m}^{2}$ \\
\hline \multirow{3}{*}{ Zembrzyce } & \multirow{3}{*}{ Riparian forest inside } & 2008 & 97 & 1.38 \\
\hline & & 2009 & 146 & 2.08 \\
\hline & & 2010 & 217 & 3.10 \\
\hline \multirow[t]{3}{*}{ Zembrzyce } & \multirow{3}{*}{ Riparian forest edge } & 2008 & 43 & 0.57 \\
\hline & & 2009 & 86 & 1.14 \\
\hline & & 2010 & 94 & 1.25 \\
\hline \multirow[t]{3}{*}{ Zembrzyce } & \multirow[t]{3}{*}{ Willow thickets } & 2008 & 33 & 0.55 \\
\hline & & 2009 & 65 & 1.08 \\
\hline & & 2010 & 76 & 1.26 \\
\hline \multirow[t]{3}{*}{ Szczawa } & \multirow{3}{*}{$\begin{array}{l}\text { Roadside dominated } \\
\text { by herbs creating several } \\
\text { branches and wide leaves }\end{array}$} & 2008 & 68 & 1.36 \\
\hline & & 2009 & 79 & 1.58 \\
\hline & & 2010 & 85 & 1.70 \\
\hline \multirow[t]{3}{*}{ Podobin } & \multirow{3}{*}{$\begin{array}{l}\text { Roadside dominated } \\
\text { by herbs forming upright } \\
\text { and narrow leaves }\end{array}$} & 2008 & 38 & 0.63 \\
\hline & & 2009 & 54 & 0.90 \\
\hline & & 2010 & 75 & 1.25 \\
\hline
\end{tabular}

The light intensity at the soil level was surveyed with a digital light meter Voltcraft MS-1300 (accuracy $+/-5 \%$ +10 digits; measuring range $0.01-50000 \mathrm{~lx}$ ). In total, 10 measurements per site were taken between $12^{\text {th }}$ and $28^{\text {th }}$ of August 2008. Five measurements were performed in the sunny days and the other five in the clouded ones. The statistical analysis performed using the $\mathrm{H}$ Kruskal-Wallis test showed that the study sites differed significantly in values of the height of vascular plants cover and the light intensity.

The investigations of performance of Impatiens glandulifera and Bidens frondosa within the bordered study sites were conducted in the years 2008-2010. Each year, all individuals (stems) occurring in the particular sites were inventoried in August. In all sites the density of individuals understood as the number of stems per $\mathrm{m}^{2}$ were calculated. This parameter is particularly useful for comparison of population size in sites with different area. Next, 30 randomly chosen stems were marked with plastic rings. The individuals with rings were measured and all the fruits were counted. In order to avoid re-counting each counted fruit was marked with fluorescent marker. The number of seeds was surveyed in 30 randomly collected fruits. To perform biometric tests of the seeds, 30 capsules of Impatiens glandulifera and 15 Bidens frondosa capitules were sampled in the third week of September of each year. The length and the maximum width of all the seeds were measured with a caliper. To verify the seedling recruitment 500 mature seeds were collected from each population of Bidens frondosa and Impatiens glandulifera in each vegetative season. The seeds were then placed in potable water to imbibe. The imbibed Impatiens glandulifera seeds were subjected to cold stratification by placing them in a refrigerator at a temperature of $4^{\circ} \mathrm{C}$ for three months. The seeds from each Bidens frondosa and Impatiens glandulifera population were sown in groups of 50 into 10 pots filled with "Geovita" soil placed in a greenhouse with a constant temperature of $30^{\circ} \mathrm{C}$, at $12 / 12 \mathrm{~h}$ day/night treatment. The pots were watered three times a week. Seedling recruitment was observed three times a week (every two days) for a period of one month. The newly formed seedlings were removed each time.

The statistical analysis

The statistical analysis was carried out on untransformed data of height of individuals, number of fruits per stem, number of seeds per fruit, as well as the seedling abundance. Firstly, the normal distribution of the untransformed data was tested using the Kolmogorov-Smirnov one-sample test at the significance level of $P<0.05$. Subsequently, the variance homogeneity was tested using the Brown-Forsythe test at the significance level of $P<0.05$.

As the values of height of individuals, number of fruits per stem, number of seeds per fruit, as well as the seedling abundance in some groups were not consistent with the normal distribution and the variances were not homogeneous, the non-parametric Kruskal-Wallis test was used in statistical analyses. All the analyses were performed with $S T A$ TISTICA (version 10) software.

\section{Results}

\section{Impatiens glandulifera}

A considerable number of individuals were registered in the riparian forest $(97-217)$ and along its edges (4394 ), while smaller populations occurred in sites located along roadside areas (38-85) and in willow thickets (3376). The similar pattern presents the density of individuals per $\mathrm{m}^{2}$. In the riparian forest it achieved from 1.38 to 3.10 individuals, along the roadside areas it reached from 0.63 to 1.70 , in forest edge it ranged from 0.57 to 1.25 , whilst in thickets it amounted from 0.55 to 1.26. In all study sites the number and density of individuals increased steadily in successive seasons (Table 3 ). Individuals growing along roadside areas were considerably larger $(130.2-181.1 \mathrm{~cm})$ than those growing in willow thickets $(112.3-143.7 \mathrm{~cm})$, along the edge of the forest $(129.9-146.6 \mathrm{~cm})$ and in the riparian forest $(127.6-135.5 \mathrm{~cm})$. Plants established along roadside areas produced more fruits $(93.0-123.8)$ than individuals occurring in willow thickets (33.2-45.6), at the edge of the forest (54.3-60.1) and in the riparian forest (48.951.2 ). Also, the largest seed production per fruit observed along roadside areas (7.8-9.3) decreased gradually to reach the lowest values ( 4.6 to 5.4 ) in the riparian forest (Fig. 1). The height of stems, fruit and seed production did not showed the temporal variability but 

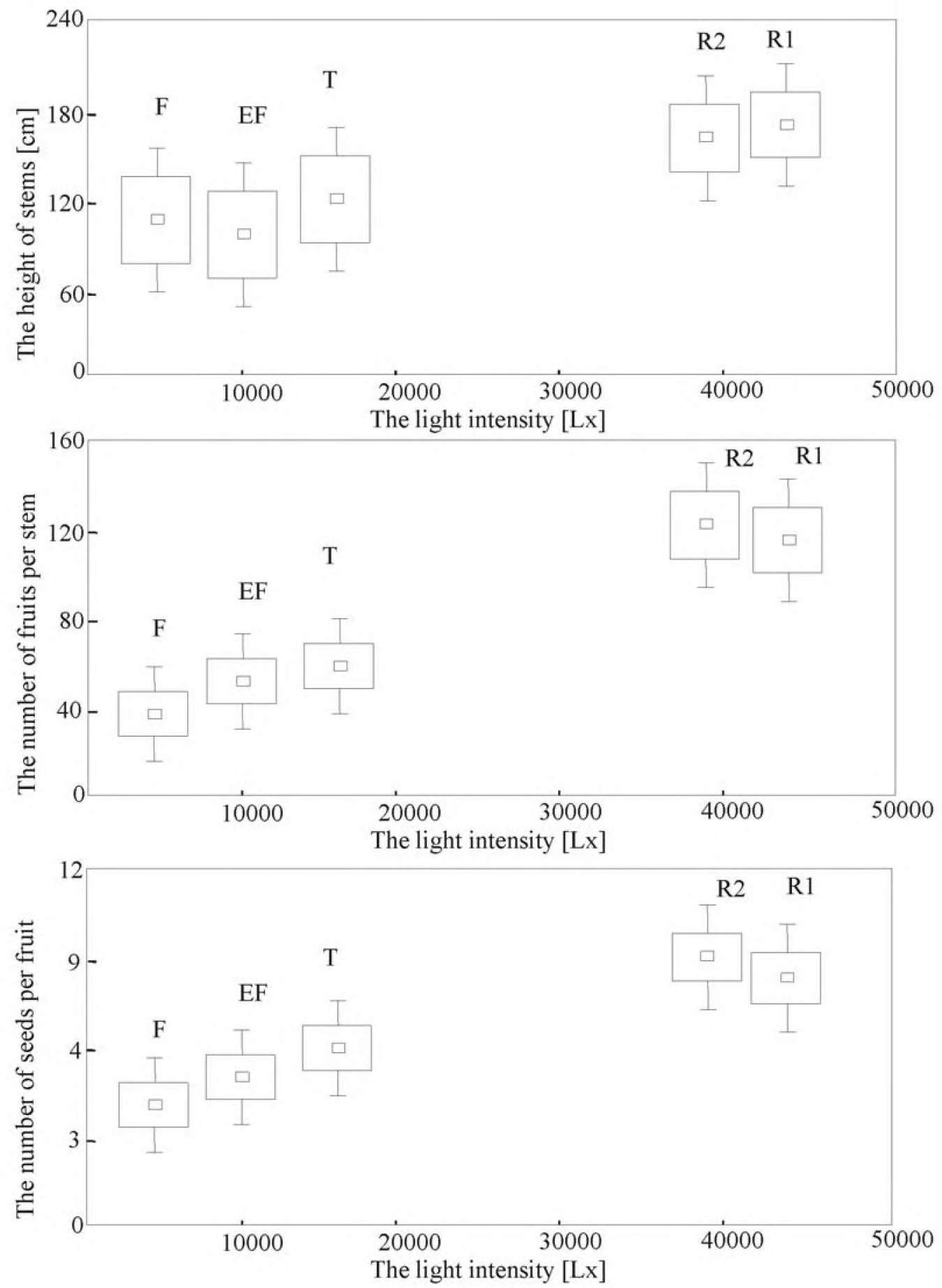

Fig. 1. The average height of individuals, the average fruit production per generative stem, the average number of seeds per fruit of Impatiens glandulifera Royle individuals in the years 2008-2010. The diagrams present the average (square), SE (box) and SD (whiskers). Abbreviations: R1, roadside dominated by herbs forming upright stems and narrow leaves; R2, roadside dominated by herbs creating several branches and wide leaves; $\mathrm{T}$, willow thickets; EF, riparian forest edge; $\mathrm{F}$, riparian forest inside.

they presented the considerable spatial diversity (Table 4). The largest seeds were produced in populations occupying roadside areas, while the smallest propagules were formed in the riparian forest (Table 5). The diaspore dimensions presented significant temporal (Tables 6,7 ) and spatial variability (Tables 8,9 ). The recruitment of seedlings derived from seeds collected from the successive sites and in consecutive seasons stayed similar (Table 10).

\section{Bidens frondosa}

The great number and density of Bidens frondosa individuals observed in shady and partly shady sites during the first year of studies raised in the second year and subsequently dramatically decreased in the third season. The lowest number and density of individuals noted in the first season in unshaded site raised substantially in subsequent years (Table 11). The tallest individuals were observed in an unshaded area (150.7- 
Table 4. The spatial variability of height of individuals, fruit production per generative stem, and number of seeds per fruit in Impatiens glandulifera Royle in the years 2008-2010. The asterisks show the statistical significance of differences at the level $\leq 0.05(*),<0.01$ $(* *),<0.001\left({ }^{* *}\right)$; ns- not significant differences (The H Kruskal-Walis test; $\mathrm{d} f=4$ ).

\begin{tabular}{|c|c|c|c|}
\hline \multirow{11}{*}{$\begin{array}{l}\text { The hight } \\
\text { of generative stems }\end{array}$} & \multicolumn{2}{|l|}{ The value of Kruskal-Wallis test among all study sites } & \multirow{2}{*}{$\frac{114.34^{* * *}}{\mathrm{~ns}}$} \\
\hline & The level of statistical significance of differences among sites: & $\mathrm{F}$ and $\mathrm{EF}$ & \\
\hline & & $\mathrm{F}$ and $\mathrm{T}$ & ns \\
\hline & & $\mathrm{F}$ and $\mathrm{R} 2$ & $<0.001$ \\
\hline & & $\mathrm{F}$ and $\mathrm{R} 1$ & $<0.001$ \\
\hline & & $\mathrm{EF}$ and $\mathrm{T}$ & ns \\
\hline & & $\mathrm{EF}$ and $\mathrm{R} 2$ & $<0.001$ \\
\hline & & $\mathrm{EF}$ and $\mathrm{R} 1$ & $<0.001$ \\
\hline & & $\mathrm{T}$ and $\mathrm{R} 2$ & $<0.001$ \\
\hline & & $\mathrm{T}$ and R1 & $<0.001$ \\
\hline & & $\mathrm{R} 1$ and $\mathrm{R} 2$ & ns \\
\hline \multirow{11}{*}{$\begin{array}{l}\text { Number of fruits } \\
\text { per generative stem }\end{array}$} & \multicolumn{2}{|l|}{ The value of Kruskal-Wallis test among all study sites } & $202.39^{* * *}$ \\
\hline & The level of statistical significance of differences among sites: & $\mathrm{F}$ and $\mathrm{EF}$ & $\mathrm{ns}$ \\
\hline & & $\mathrm{F}$ and $\mathrm{T}$ & ns \\
\hline & & $\mathrm{F}$ and $\mathrm{R} 2$ & $<0.001$ \\
\hline & & $\mathrm{F}$ and R1 & $<0.001$ \\
\hline & & $\mathrm{EF}$ and $\mathrm{T}$ & $\leq 0.05$ \\
\hline & & $\mathrm{EF}$ and $\mathrm{R} 2$ & $\overline{<} 0.001$ \\
\hline & & EF and R1 & $<0.001$ \\
\hline & & $\mathrm{T}$ and $\mathrm{R} 2$ & $<0.001$ \\
\hline & & $\mathrm{T}$ and $\mathrm{R} 1$ & $<0.001$ \\
\hline & & $\mathrm{R} 1$ and $\mathrm{R} 2$ & ns \\
\hline \multirow{11}{*}{$\begin{array}{l}\text { The number of seeds } \\
\text { per fruit }\end{array}$} & \multicolumn{2}{|l|}{ The value of Kruskal-Wallis test among all study sites } & $181.67^{* * *}$ \\
\hline & The level of statistical significance of differences among sites: & $\mathrm{F}$ and $\mathrm{EF}$ & $\leq 0.05$ \\
\hline & & $\mathrm{F}$ and $\mathrm{T}$ & $<0.01$ \\
\hline & & $\mathrm{F}$ and $\mathrm{R} 2$ & $<0.001$ \\
\hline & & $\mathrm{F}$ and $\mathrm{R} 1$ & $<0.001$ \\
\hline & & $\mathrm{EF}$ and $\mathrm{T}$ & ns \\
\hline & & $\mathrm{EF}$ and $\mathrm{R} 2$ & $<0.001$ \\
\hline & & $\mathrm{EF}$ and $\mathrm{R} 1$ & $<0.001$ \\
\hline & & $\mathrm{T}$ and $\mathrm{R} 2$ & $<0.001$ \\
\hline & & $\mathrm{T}$ and $\mathrm{R} 1$ & $<0.001$ \\
\hline & & $\mathrm{R} 1$ and $\mathrm{R} 2$ & ns \\
\hline
\end{tabular}

Abbreviations: R1, roadside dominated by herbs forming upright stems and narrow leaves; R2, roadside dominated by herbs creating several branches and wide leaves; $\mathrm{T}$, willow thickets; $\mathrm{EF}$, riparian forest edge; $\mathrm{F}$, riparian forest inside.

Table 5. The mean length and width of seeds of Impatiens glandulifera Royle in studied localities in the years $2008-2010$.

\begin{tabular}{|c|c|c|c|c|c|}
\hline $\begin{array}{l}\text { Population } \\
\text { locality }\end{array}$ & Habitat & Year & $\begin{array}{l}\text { The measured } \\
\text { seed number }\end{array}$ & $\begin{array}{l}\text { The average length } \\
\text { of seeds (SD) [mm] }\end{array}$ & $\begin{array}{l}\text { The average width } \\
\text { of seeds (SD) }[\mathrm{mm}]\end{array}$ \\
\hline Zembrzyce & Riparian forest inside & $\begin{array}{l}2008 \\
2009 \\
2010\end{array}$ & $\begin{array}{l}147 \\
130 \\
118\end{array}$ & $\begin{array}{l}4.31(0.14) \\
4.30(0.14) \\
4.30(0.11)\end{array}$ & $\begin{array}{l}3.23(0.14) \\
3.23(0.11) \\
3.25(0.13)\end{array}$ \\
\hline Zembrzyce & Riparian forest edge & $\begin{array}{l}2008 \\
2009 \\
2010\end{array}$ & $\begin{array}{l}178 \\
154 \\
178\end{array}$ & $\begin{array}{l}4.40(0.15) \\
4.28(0.12) \\
4.33(0.12)\end{array}$ & $\begin{array}{l}3.31(0.14) \\
3.23(0.16) \\
3.23(0.13)\end{array}$ \\
\hline Zembrzyce & Willow thickets & $\begin{array}{l}2008 \\
2009 \\
2010\end{array}$ & $\begin{array}{l}168 \\
176 \\
191\end{array}$ & $\begin{array}{l}4.60(0.12) \\
4.48(0.13) \\
4.40(0.13)\end{array}$ & $\begin{array}{l}3,52(0.13) \\
3.41(0.15) \\
3.32(0.12)\end{array}$ \\
\hline Szczawa & $\begin{array}{l}\text { Roadside dominated by herbs creating } \\
\text { several branches and wide leaves }\end{array}$ & $\begin{array}{l}2008 \\
2009 \\
2010\end{array}$ & $\begin{array}{l}280 \\
361 \\
365\end{array}$ & $\begin{array}{l}4.80(0.14) \\
4.68(0.29) \\
4.88(0.27)\end{array}$ & $\begin{array}{l}3.69(0.27) \\
3.82(0.24) \\
3.64(0.31)\end{array}$ \\
\hline Podobin & $\begin{array}{l}\text { Roadside dominated by herbs forming } \\
\text { upright stems and narrow leaves }\end{array}$ & $\begin{array}{l}2008 \\
2009 \\
2010\end{array}$ & $\begin{array}{l}342 \\
313 \\
325\end{array}$ & $\begin{array}{l}4.68(0.24) \\
4.77(0.20) \\
4.94(0.16)\end{array}$ & $\begin{array}{l}3.60(0.30) \\
3.82(0.24) \\
3.90(0.17)\end{array}$ \\
\hline
\end{tabular}


Table 6. The temporal variability of length of seeds of Impatiens glandulifera Royle. The asterisks show the statistical significance of differences at the level $\leq 0.05\left(^{*}\right),<0.01\left(^{* *}\right),<0.001\left(^{* *}\right)$; ns - not significant differences (The H Kruskal-Walis test; df $=4$ ).

\begin{tabular}{|c|c|c|c|c|c|c|}
\hline Site & & $\mathrm{F}$ & $\mathrm{EF}$ & $\mathrm{T}$ & $\mathrm{R} 2$ & R1 \\
\hline The value of Kruskal-Wallis test & & $12.51^{*}$ & $50.96^{* * *}$ & $142.43^{* * *}$ & $40.20^{* * *}$ & $191.61^{* * *}$ \\
\hline $\begin{array}{l}\text { The level of statistical significance } \\
\text { of differences among years: }\end{array}$ & $\begin{array}{l}2008 \text { and } 2009 \\
2008 \text { and } 2010 \\
2009 \text { and } 2010\end{array}$ & $\begin{array}{l}\leq 0.05 \\
\leq 0.05 \\
\text { ns }\end{array}$ & $\begin{array}{l}<0.001 \\
<0.001 \\
\leq 0.05\end{array}$ & $\begin{array}{c}<0.001 \\
\text { ns } \\
<0.001\end{array}$ & $\begin{array}{c}\text { ns } \\
<0.001 \\
<0.001\end{array}$ & $\begin{array}{l}<0.001 \\
<0.001 \\
<0.001\end{array}$ \\
\hline
\end{tabular}

Abbreviations: R1, roadside dominated by herbs forming upright stems and narrow leaves; R2, roadside dominated by herbs creating several branches and wide leaves; T, willow thickets; EF, riparian forest edge; F, riparian forest inside.

Table 7. The temporal variability of width of seeds of Impatiens glandulifera Royle. The asterisks show the statistical significance of differences at the level $\leq 0.05(*),<0.01\left(^{* *}\right),<0.001\left(^{* * *}\right)$; ns - not significant differences (The H Kruskal-Walis test; df $=4$ ).

\begin{tabular}{|c|c|c|c|c|c|c|}
\hline Site & & $\mathrm{F}$ & $\mathrm{EF}$ & $\mathrm{T}$ & $\mathrm{R} 2$ & $\mathrm{R} 1$ \\
\hline The value of Kruskal-Wallis test & & $33.21^{*}$ & $237.22^{* * *}$ & $42.93^{* * *}$ & $7.05^{*}$ & $169.92^{* * *}$ \\
\hline $\begin{array}{l}\text { The level of statistical significance } \\
\text { of differences among years: }\end{array}$ & $\begin{array}{l}2008 \text { and } 2009 \\
2008 \text { and } 2010 \\
2009 \text { and } 2010\end{array}$ & $\begin{array}{l}<0.001 \\
\leq 0.05 \\
\leq 0.05\end{array}$ & $\begin{array}{c}<0.001 \\
<0.001 \\
\text { ns }\end{array}$ & $\begin{array}{l}<0.001 \\
<0.001 \\
\text { ns }\end{array}$ & $\begin{array}{l}\leq 0.05 \\
\mathrm{~ns} \\
\mathrm{~ns}\end{array}$ & $\begin{array}{l}<0.001 \\
<0.001 \\
<0.001\end{array}$ \\
\hline
\end{tabular}

Abbreviations: R1, roadside dominated by herbs forming upright stems and narrow leaves; R2, roadside dominated by herbs creating several branches and wide leaves; $\mathrm{T}$, willow thickets; $\mathrm{EF}$, riparian forest edge; $\mathrm{F}$, riparian forest inside.

Table 8. The spatial variability of length of seeds of Impatiens glandulifera Royle. The asterisks show the statistical significance of differences at the level $\leq 0.05\left(^{*}\right),<0.01\left(^{* *}\right),<0.001\left(^{* *}\right)$; ns - not significant differences $($ The H Kruskal-Walis test; df $=4$ ).

\begin{tabular}{|c|c|c|c|c|}
\hline \multicolumn{2}{|l|}{ Year } & 2008 & 2009 & 2010 \\
\hline \multicolumn{2}{|c|}{ The value of Kruskal-Wallis test among all study patches } & $376.51^{* * *}$ & $680.33^{* * *}$ & $872.62^{* * *}$ \\
\hline \multirow{10}{*}{$\begin{array}{l}\text { The level of statistical } \\
\text { significance of differences } \\
\text { among sites: }\end{array}$} & $\mathrm{F}$ and $\mathrm{EF}$ & $<0.001$ & ns & $\leq 0.05$ \\
\hline & $\mathrm{F}$ and $\mathrm{T}$ & $<0.001$ & $<0.001$ & ns \\
\hline & $\mathrm{F}$ and $\mathrm{R} 2$ & $<0.001$ & $<0.001$ & $<0.001$ \\
\hline & $\mathrm{F}$ and $\mathrm{R} 1$ & $<0.001$ & $<0.001$ & $<0.001$ \\
\hline & $\mathrm{EF}$ and $\mathrm{T}$ & $\mathrm{ns}$ & $<0.001$ & ns \\
\hline & $\mathrm{EF}$ and $\mathrm{R} 2$ & $<0.001$ & $<0.001$ & $<0.001$ \\
\hline & $\mathrm{EF}$ and R1 & $<0.001$ & $<0.001$ & $<0.001$ \\
\hline & $\mathrm{T}$ and $\mathrm{R} 2$ & $<0.001$ & $<0.001$ & $<0.001$ \\
\hline & $\mathrm{T}$ and $\mathrm{R} 1$ & $<0.001$ & $\leq 0.05$ & $<0.001$ \\
\hline & $\mathrm{R} 1$ and $\mathrm{R} 2$ & ns & $\overline{<} 0.001$ & $<0.001$ \\
\hline
\end{tabular}

Abbreviations: R1, roadside dominated by herbs forming upright stems and narrow leaves; R2, roadside dominated by herbs creating several branches and wide leaves; $\mathrm{T}$, willow thickets; $\mathrm{EF}$, riparian forest edge; F, riparian forest inside.

Table 9. The spatial variability of width of seeds of Impatiens glandulifera Royle. The asterisks show the statistical significance of differences at the level $\leq 0.05\left(^{*}\right),<0.01\left(^{* *}\right),<0.001\left(^{* *}\right)$; ns - not significant differences (The H Kruskal-Walis test; df $=4$ ).

\begin{tabular}{|c|c|c|c|c|}
\hline \multicolumn{2}{|l|}{ Year } & 2008 & 2009 & 2010 \\
\hline \multicolumn{2}{|c|}{ The value of Kruskal-Wallis test among all study sites } & $423.41^{* * *}$ & $704.19^{* * *}$ & $875.32^{* * *}$ \\
\hline \multirow[t]{10}{*}{ The level of statistical } & $\mathrm{F}$ and $\mathrm{EF}$ & $<0.001$ & $\mathrm{~ns}$ & ns \\
\hline & $\mathrm{F}$ and $\mathrm{T}$ & $\leq 0.05$ & $<0.001$ & ns \\
\hline & $\mathrm{F}$ and $\mathrm{R} 2$ & $\leq 0.05$ & $<0.001$ & $<0.001$ \\
\hline & $\mathrm{F}$ and $\mathrm{R} 1$ & $\overline{<} 0.001$ & $<0.001$ & $<0.001$ \\
\hline & $\mathrm{EF}$ and $\mathrm{T}$ & $<0.001$ & $<0.001$ & $\leq 0.05$ \\
\hline & EF and R2 & $<0.001$ & $<0.001$ & $\overline{<} 0.001$ \\
\hline & EF and R1 & $\leq 0.05$ & $<0.001$ & $<0.001$ \\
\hline & $\mathrm{T}$ and $\mathrm{R} 2$ & $\overline{<0} 001$ & $<0.001$ & $<0.001$ \\
\hline & $\mathrm{T}$ and $\mathrm{R} 1$ & $<0.001$ & $<0.001$ & $<0.001$ \\
\hline & $\mathrm{R} 1$ and $\mathrm{R} 2$ & $\leq 0.05$ & $<0.001$ & $<0.001$ \\
\hline
\end{tabular}

Abbreviations: R1, roadside dominated by herbs forming upright stems and narrow leaves; R2, roadside dominated by herbs creating several branches and wide leaves; T, willow thickets; $\mathrm{EF}$, riparian forest edge; $\mathrm{F}$, riparian forest inside. 

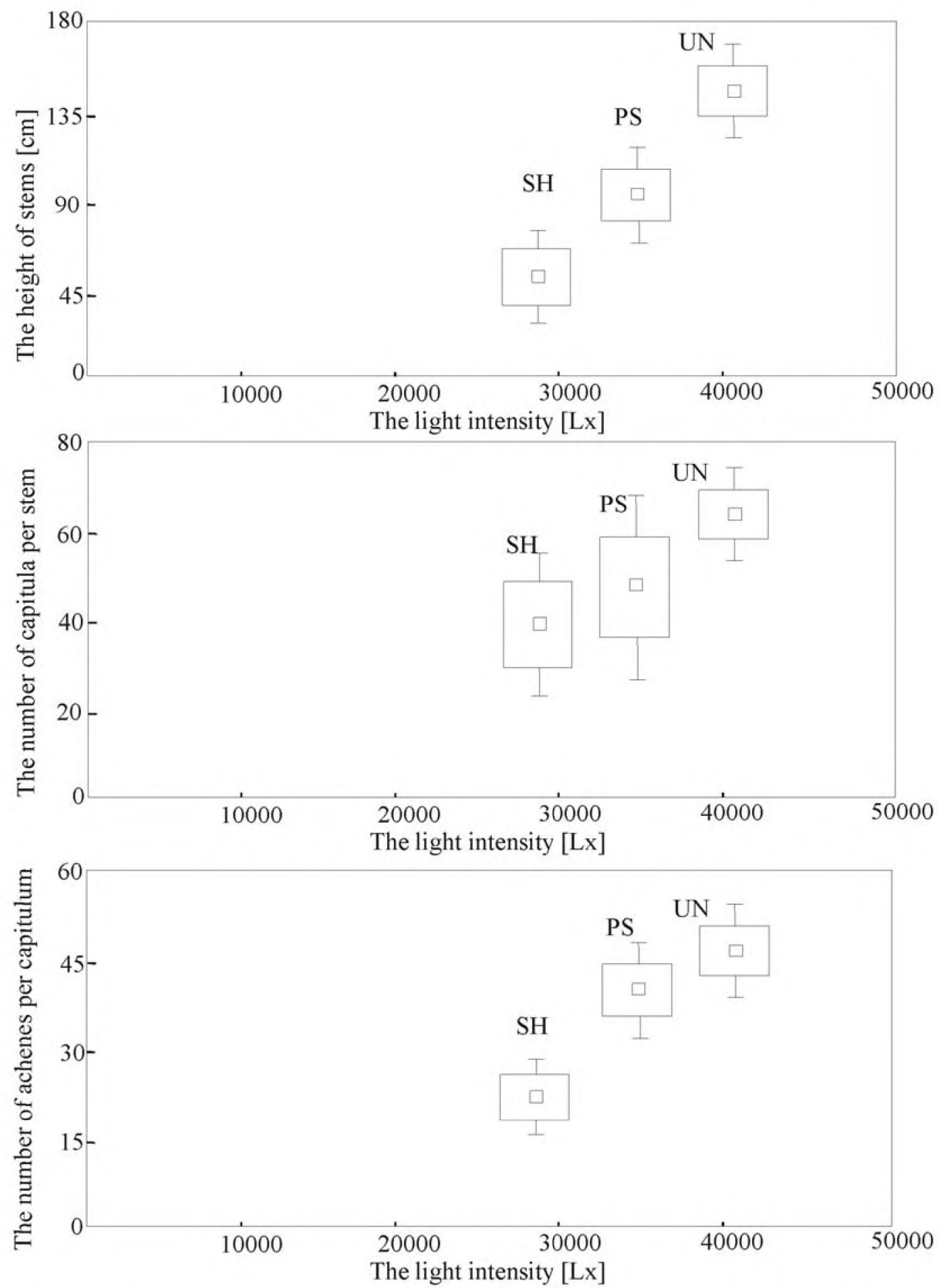

Fig. 2. The average height of individuals, the average production of capitula per generative stem, the average number of achenes per capitulum of Bidens frondosa L. individuals in the years 2008-2010. The diagrams present the average (square), SE (box) and SD (whiskers). Abbreviations: UN, unshaded gravel; PS, partly shaded gravel; SH, shaded gravel.

$159.8 \mathrm{~cm})$, significantly shorter stems occurred in a partly shaded site $(49.7-57.9 \mathrm{~cm})$, while the lowest shoots were found in a shady location $(39.3-49.6 \mathrm{~cm})$. The highest capitula production was observed in a sunheated area (50.7 to 58.0 ), while the lowest fruit number was noted in a shady place (35.7 to 39.6 ). The number of seeds per capitula found in the sunny place (46.0 to $50.1)$ considerably exceeds that recorded for the partly shady area (33.8 do 45.6) and the shady area (16.6 to 28.9) (Fig. 2). The height of stems, fruit and seed production, as well as the diaspore dimensions did not showed the temporal variability but they presented the substantial spatial diversity (Tables 12). The largest seeds were produced in the sunny area, while the smallest propagules were observed in the shady area (Table 13). The diaspore dimensions presented significant temporal (Tables 14, 15) and spatial variability (Tables 16,17$)$. The emergence of seedlings derived from 
Table 10. The percentage of germinated seeds of Impatiens glandulifera Royle. derived from studied localities.

\begin{tabular}{|c|c|c|c|c|c|c|}
\hline \multirow{2}{*}{ Population locality } & \multirow{2}{*}{ Habitat } & \multirow{2}{*}{ Year } & \multirow{2}{*}{$\begin{array}{l}\text { The number } \\
\text { of sown seeds }\end{array}$} & \multicolumn{3}{|c|}{ The percentage of germinated seeds } \\
\hline & & & & Minimal & Maximal & Mean \\
\hline \multirow[t]{3}{*}{ Zembrzyce } & \multirow[t]{3}{*}{ Riparian forest inside } & 2008 & 50 & 42.00 & 98.00 & 68.44 \\
\hline & & 2009 & 50 & 38.00 & 84.00 & 54.89 \\
\hline & & 2010 & 50 & 8.00 & 98.00 & 56.00 \\
\hline \multirow[t]{3}{*}{ Zembrzyce } & \multirow{3}{*}{ Riparian forest edge } & 2008 & 50 & 16.00 & 84.00 & 48.22 \\
\hline & & 2009 & 50 & 10.00 & 78.00 & 43.56 \\
\hline & & 2010 & 50 & 16.00 & 82.00 & 45.11 \\
\hline \multirow{3}{*}{ Zembrzyce } & \multirow{3}{*}{ Willow thickets } & 2008 & 50 & 8.00 & 84.00 & 55.33 \\
\hline & & 2009 & 50 & 36.00 & 94.00 & 58.89 \\
\hline & & 2010 & 50 & 10.00 & 78.00 & 51.11 \\
\hline \multirow[t]{3}{*}{ Szczawa } & \multirow{3}{*}{$\begin{array}{l}\text { Roadside dominated by herbs } \\
\text { creating several branches and wide leaves }\end{array}$} & 2008 & 50 & 24.00 & 90.00 & 59.77 \\
\hline & & 2009 & 50 & 28.00 & 82.00 & 64.89 \\
\hline & & 2010 & 50 & 18.00 & 84.00 & 55.89 \\
\hline \multirow[t]{3}{*}{ Podobin } & \multirow{3}{*}{$\begin{array}{l}\text { Roadside dominated by herbs forming } \\
\text { upright stems and narrow leaves }\end{array}$} & 2008 & 50 & 10.00 & 92.00 & 54.89 \\
\hline & & 2009 & 50 & 20.00 & 84.00 & 55.11 \\
\hline & & 2010 & 50 & 18.00 & 82.00 & 55.11 \\
\hline
\end{tabular}

Table 11. The abundance and density of individuals of Bidens frondosa L. in studied localities in the years 2008-2010.

\begin{tabular}{|c|c|c|c|c|}
\hline Population locality & Habitat & Year & The total number of individuals & The number of individuals per $\mathrm{m}^{2}$ \\
\hline \multirow[t]{3}{*}{ Żbikowice } & The shaded gravel & 2008 & 76 & 0.95 \\
\hline & & 2009 & 81 & 1.01 \\
\hline & & 2010 & 53 & 0.66 \\
\hline \multirow[t]{3}{*}{ Osieczany } & The party shaded gravel & 2008 & 56 & 0.65 \\
\hline & & 2009 & 85 & 0.98 \\
\hline & & 2010 & 66 & 0.76 \\
\hline \multirow{3}{*}{ Soboniowice } & The unshaded gravel & 2008 & 41 & 0.41 \\
\hline & & 2009 & 95 & 0.95 \\
\hline & & 2010 & 101 & 1.01 \\
\hline
\end{tabular}

seeds collected from the studied sites and in consecutive years remained similar (Table 18).

\section{Discussion}

\section{Impatiens glandulifera}

The performed observations showed that the number of the Impatiens glandulifera individuals was considerably higher in the riparian forest than in other habitats. A low number of the Impatiens glandulifera individuals in the forest edge might be caused by physical damage, while low abundance of plants in the thickets may be caused by seasonal flooding of the seeds in hollows with stagnant water. The unfavorable effects of stagnant water on the development of individuals of this species have been observed by Perrins et al. (1993) and Skálová et al. (2012). On the other hand, the moderate abundance of individuals occurred along sunny roadside areas might be caused by drying the seeds. Such unfavorable influence of water deficiency on population size was previously observed in Impatiens pallida (Bennington \& McGraw 1995). The obtained results might suggest that the smaller populations might be also younger. The lower number of individuals observed during colo- nization of new area and subsequent raise of population size were observed in several annuals occurred in wide range of habitats (Falińska 2002).

The recorded steadily increase of number of individuals in consecutive years might suggest the lack of dramatic disturbances in studied sites, such as inundations, drought, slug predation or viral diseases (Prowse 1998; Kasperek 2004; Kollmann et al. 2007). Moreover, the increase of number of individuals in open sites might be due to great fecundity of individuals. The performed observations showing substantial production of fruits and seeds in sites dominated by low stature species correspond with the results obtained by Willis \& Hulme (2004). The aforementioned authors noted a considerably higher reproductive ability in individuals growing in sunny areas than with those in shady sites. An increase in the individual reproductive ability in sites characterized by a lower number of neighboring species was found in Impatiens capensis (Schmidt et al. 1987) and Impatiens parviflora populations (Piskorz 2005). The greater fruit production in open sites than in closed habitats might be caused by better accessibility of flowers Impatiens species for pollinators, which are small-sized Syrphidae and Apidae 
Table 12. The spatial variability of height of individuals, fruit production per generative stem, and number of seeds per fruit in Bidens frondos $a$ L. in the years 2008-2010. The asterisks show the statistical significance of differences at the level $\leq 0.05(*),<0.01(* *)$, $<0.001\left(^{* * *}\right)$; ns - not significant differences (The H Kruskal-Walis test; $d f=2$ )

\begin{tabular}{|c|c|c|c|}
\hline \multirow{2}{*}{$\begin{array}{l}\text { The height of } \\
\text { generative stems }\end{array}$} & \multicolumn{2}{|c|}{ The value of Kruskal-Wallis test among all study sites } & $190.60^{* * *}$ \\
\hline & $\begin{array}{l}\text { The level of statistical significance } \\
\text { of differences among sites: }\end{array}$ & $\begin{array}{l}\mathrm{SH} \text { and PS } \\
\mathrm{SH} \text { and UNS } \\
\mathrm{PS} \text { and UNS }\end{array}$ & $\begin{array}{l}<0.001 \\
<0.001 \\
<0.001\end{array}$ \\
\hline \multirow{2}{*}{$\begin{array}{l}\text { Number of fruits } \\
\text { per generative stem }\end{array}$} & \multicolumn{2}{|c|}{ The value of Kruskal-Wallis test among all study patches } & $32.31^{* * *}$ \\
\hline & $\begin{array}{l}\text { The level of statistical significance } \\
\text { of differences among sites: }\end{array}$ & $\begin{array}{l}\text { SH and PS } \\
\text { SH and UNS } \\
\text { PS and UNS }\end{array}$ & $\begin{array}{l}\leq 0.05 \\
<0.001 \\
\leq 0.05\end{array}$ \\
\hline \multirow{2}{*}{$\begin{array}{l}\text { The number of } \\
\text { seeds per fruit }\end{array}$} & \multicolumn{2}{|c|}{ The value of Kruskal-Wallis test among all study patches } & $85.40^{* * *}$ \\
\hline & $\begin{array}{l}\text { The level of statistical significance } \\
\text { of differences among sites: }\end{array}$ & $\begin{array}{l}\text { SH and PS } \\
\text { SH and UNS } \\
\text { PS and UNS }\end{array}$ & $\begin{array}{l}<0.01 \\
<0.001 \\
<0.001\end{array}$ \\
\hline
\end{tabular}

Abbreviations: SH, shaded gravel; PS, partly shaded gravel; UNS, not shaded gravel.

Table 13. The mean length and width of seeds of Bidens frondosa L. in studied localities in the years 2008-2010.

\begin{tabular}{|c|c|c|c|c|c|}
\hline $\begin{array}{l}\text { Population } \\
\text { locality }\end{array}$ & Habitat & Year & $\begin{array}{l}\text { The number of } \\
\text { measured seeds }\end{array}$ & $\begin{array}{l}\text { The average length } \\
\text { of seeds (SD) [mm] }\end{array}$ & $\begin{array}{l}\text { The average width } \\
\text { of seeds (SD) [mm] }\end{array}$ \\
\hline \multirow[t]{3}{*}{ Żbikowice } & The shaded gravel & 2008 & 321 & $6.97(0.22)$ & $1.95(0.16)$ \\
\hline & & 2009 & 354 & $7.04(0.19)$ & $1.94(0.25)$ \\
\hline & & 2010 & 394 & $6.96(0.25)$ & $2.03(0.17)$ \\
\hline \multirow[t]{3}{*}{ Osieczany } & The party shaded gravel & 2008 & 512 & $7.34(0.54)$ & $2.31(0.30)$ \\
\hline & & 2009 & 642 & $7.33(0.27)$ & $2.00(0.18)$ \\
\hline & & 2010 & 614 & $7.30(0.26)$ & $2.04(0.13)$ \\
\hline \multirow[t]{3}{*}{ Soboniowice } & The unshaded gravel & 2008 & 756 & $7.41(0.62)$ & $2.48(0.32)$ \\
\hline & & 2009 & 768 & $8.17(0.45)$ & $2.34(0.24)$ \\
\hline & & 2010 & 716 & $8.31(0.42)$ & $2.34(0.25)$ \\
\hline
\end{tabular}

Table 14. The temporal variability of lenght of seeds of Bidens frondosa L. . The asterisks show the statistical significance of differences at the level $\leq 0.05(*),<0.01\left({ }^{*}\right),<0.001\left(*^{* *}\right)$; ns - not significant differences (The H Kruskal-Walis test; $\mathbf{d f}=2$ ).

\begin{tabular}{|c|c|c|c|c|}
\hline Site & & $\mathrm{SH}$ & PS & UNS \\
\hline The value of Kruskal-Wallis test & & $60.37^{* *}$ & $15.83^{*}$ & $163.33^{* * *}$ \\
\hline $\begin{array}{l}\text { The level of statistical significance } \\
\text { of differences among years: }\end{array}$ & $\begin{array}{l}2008 \text { and } 2009 \\
2008 \text { and } 2010 \\
2009 \text { and } 2010\end{array}$ & $\begin{array}{c}<0.001 \\
\text { ns } \\
<0.001\end{array}$ & $\begin{array}{c}\text { ns } \\
\text { ns } \\
<0.001\end{array}$ & $\begin{array}{l}<0.001 \\
<0.001 \\
<0.001\end{array}$ \\
\hline
\end{tabular}

Abbreviations: SH, shaded gravel; PS, partly shaded gravel; UNS, not shaded gravel.

(Nienhuis \& Stout 2009; Vervoort et al. 2011). On the other hand, the obtained results documented that even much lower fruit production in thickets and forest also might contribute to substantial increase of individual abundance. Performed observations showed that larger seeds were produced in roadsides characterized by great irradiance level, than in partly shaded willow thickets and shaded edge and inside of riparian forest. These results suggest that higher level of intercepted solar radiation increased seed dimensions. On the other hand, Willis \& Hulme (2004) argued that seed mass was negatively correlated with the heat sum over the period of seed maturation. Regardless of temporal variability of seed dimensions observed in all sites, each year the considerable establishment of seedlings was recorded. The high emergence of seedlings originated from seeds collected in different sites confirmed findings of Perglová et al. (2009). In light of performed investigations, it might be concluded that the considerable establishment of seedlings observed during experiment might also contribute to increase of abundance of individuals in natural conditions.

The relatively low height of Impatiens glandulifera individuals observed in forest and thickets communities can be caused by intraspecific competition for light, water and nutrients, which becomes more intense with the 
Table 15. The temporal variability of width of seeds of Bidens frondosa $\mathrm{L}$. The asterisks show the statistical significance of differences at the level $\leq 0.05(*),<0.01\left(^{* *}\right),<0.001\left(^{* *}\right)$; ns - not significant differences (The H Kruskal-Walis test; df $=2$ ).

\begin{tabular}{lcccc}
\hline Site & SH & PS & UNS \\
\hline The value of Kruskal-Wallis test & & $109.35^{* * *}$ & $185.21^{* * *}$ & $150.57^{* * *}$ \\
\hline The level of statistical significance & 2008 and 2009 & ns & $<0.001$ & $<0.001$ \\
of differences among years: & 2008 and 2010 & $<0.001$ & $<0.001$ & $<0.001$ \\
& 2009 and 2010 & $<0.001$ & $<0.001$ & ns \\
\hline
\end{tabular}

Abbreviations: SH, shaded gravel; PS, partly shaded gravel; UNS, not shaded gravel.

Table 16. The spatial variability of lenght of seeds of Bidens frondosa L. The asterisks show the statistical significance of differences at the level $\leq 0.05(*),<0.01\left(^{* *}\right),<0.001\left({ }^{* *}\right)$; ns - not significant differences (The H Kruskal-Walis test; df $=2$ ).

\begin{tabular}{|c|c|c|c|c|}
\hline Site & & $\mathrm{SH}$ & PS & UNS \\
\hline The value of Kruskal-Wallis test & & $107.03^{* * *}$ & $131.09^{* * *}$ & $189.52^{* * *}$ \\
\hline $\begin{array}{l}\text { The level of statistical significance } \\
\text { of differences among sites: }\end{array}$ & $\begin{array}{l}\mathrm{SH} \text { and } \mathrm{PS} \\
\mathrm{SH} \text { and UNS } \\
\mathrm{PS} \text { and UNS }\end{array}$ & $\begin{array}{l}<0.001 \\
<0.001 \\
<0.001\end{array}$ & $\begin{array}{l}<0.001 \\
<0.001 \\
<0.001\end{array}$ & $\begin{array}{l}<0.001 \\
<0.001 \\
<0.001\end{array}$ \\
\hline
\end{tabular}

Abbreviations: SH, shaded gravel; PS, partly shaded gravel; UNS, not shaded gravel.

Table 17. The spatial variability of width of seeds of Bidens frondosa L. The asterisks show the statistical significance of differences at the level $\leq 0.05\left({ }^{*}\right),<0.01\left({ }^{* *}\right),<0.001\left({ }^{* *}\right)$; ns - not significant differences (The H Kruskal-Walis test; df $=2$ ).

\begin{tabular}{lcccc}
\hline Site & & SH & PS & UNS \\
\hline The value of Kruskal-Wallis test & & $281.28^{* * *}$ & $154.19^{* * *}$ & $180.02^{* * *}$ \\
\hline $\begin{array}{l}\text { The level of statistical significance } \\
\text { of differences among sites: }\end{array}$ & SH and PS & $<0.001$ & $<0.001$ & $\mathrm{~ns}$ \\
& SH and UNS & $<0.001$ & $<0.001$ & $<0.001$ \\
& PS and UNS & $<0.001$ & $<0.001$ & $<0.001$ \\
\hline
\end{tabular}

Abbreviations: SH, shaded gravel; PS, partly shaded gravel; UNS, not shaded gravel.

Table 18. The percentage of germinated seeds of Bidens frondosa L. derived from studied localities.

\begin{tabular}{|c|c|c|c|c|c|c|}
\hline \multirow{2}{*}{ Population locality } & \multirow{2}{*}{ Habitat } & \multirow{2}{*}{ Year } & \multirow{2}{*}{$\begin{array}{l}\text { The number } \\
\text { of sown seeds }\end{array}$} & \multicolumn{3}{|c|}{ The percentage of germinated seeds } \\
\hline & & & & Minimal & Maximal & Mean \\
\hline \multirow[t]{3}{*}{ Żbikowice } & \multirow[t]{3}{*}{ The shaded gravel } & 2008 & 50 & 16.00 & 94.00 & 59.40 \\
\hline & & 2009 & 50 & 16.00 & 92.00 & 44.60 \\
\hline & & 2010 & 50 & 16.00 & 84.00 & 46.80 \\
\hline \multirow[t]{3}{*}{ Osieczany } & \multirow[t]{3}{*}{ The party shaded gravel } & 2008 & 50 & 24.00 & 92.00 & 64.40 \\
\hline & & 2009 & 50 & 20.00 & 94.00 & 61.80 \\
\hline & & 2010 & 50 & 18.00 & 96.00 & 63.80 \\
\hline \multirow[t]{3}{*}{ Soboniowice } & \multirow[t]{3}{*}{ The unshaded gravel } & 2008 & 50 & 38.00 & 96.00 & 69.00 \\
\hline & & 2009 & 50 & 30.00 & 86.00 & 56.80 \\
\hline & & 2010 & 50 & 14.00 & 90.00 & 49.80 \\
\hline
\end{tabular}

increase in population size. Andrews et al. (2005, 2009) observed that the small size of forest populations and a decrease in intraspecific competition for resources contributes to an increase in the height of the individuals. Reduced height can also be caused by being shaded by neighboring species. Furthermore, being entwined in plagiotropic shoots of Galium aparine, Humulus lupulus and Calystegia sepium may have contributed to the inhibition of growth of Impatiens glandulifera in forest communities (Prah 1994). Also, Maule et al. (2000) found that light availability is likely to be the pri- mary factor limiting total plant biomass in woodlands. On the other hand, Strømme (2012) and Skálová et al. $(2012,2013)$ observed that individuals grown under controlled conditions in artificially shaded places are significantly taller than those growing in greater light availability. The aforementioned authors claimed that tall stature provides this species with a considerable advantage in terms of light acquisition. An increase in the height of stems resulting from considerable shadiness was also observed in Impatiens pallida (Murphy et al. 2009) and Impatiens capensis populations (Dudley \& 
Schmidt 1995, 1996; Donohue \& Schmitt 1999; Weing et al. 2004). Simultaneously, McGoey \& Stinchcombe (2009) pointed out, that an increase of stem length in Impatiens capensis suggests the presence of shade avoidance syndrome (SAS).

Combining performed observations and data from literature on the effectiveness of ballistic seed dispersal compared to the height of stems and the weight of seeds of Impatiens glandulifera (Chapman \& Gray 2012), it might be concluded that the considerable length of the individuals and increased production of fruits and large seeds in open and dry sites can contribute to more effective seed dispersal, while substantial seedling recruitment enables the colonization of new, perhaps more advantageous sites. On the other hand, a decrease in the height of the individuals, fruit production and the size of seeds, as well as the considerable seedling emergence in forest communities makes it possible to stay at the colonized site and to gradually extend the area occupied by the population.

\section{Bidens frondosa}

The steadily growing number of individuals of Bidens frondosa occurred in sunny places dominated by small species with low competitive abilities is not consistent with observations conducted in Bidens pilosa populations (Cui \& He 2009). The aforementioned authors found that individuals colonize fertile areas under the canopy of shrubs more frequently than the gaps between them. The observed increase of number Bidens frondosa individuals in open site might be caused by the greatest production of fruits and seeds. Observations showing larger production of fruits and seeds in sunny places compared to shady sites are in accordance to observations carried out in populations of Sonchus arvensis (Zollinger \& Kells 1991), as well as Senecio vulgaris (Baumann et al. 2001). At the same time it should be add, that performed studies do not correspond with the results of research on Bidens pilosa populations (Chivinge \& Shweppenhauer 1995), which showed a similar reproductive ability in individuals regardless of the presence of competitive species. The gradual augmentation of number of individuals in open sites might be also influenced by production of larger seeds, than in shady places. The similar impact of irradiance level on mass of seeds was observed in Helianthus annus (Santalla et al. 2002). Moreover, the differentiation of achene dimensions and mass in various site conditions was found in several taxa from Asteraceae family (Washitani \& Nishiyama 1992; Meyer 1997; Meyer \& Carlson 2001; Gravuer et al. 2003; Riba et al. 2005; Fumanal et al. 2007). Regardless of substantial differences of size of Bidens frondosa seeds among consecutive sites and years the recruitment values did not showed the spatial and temporal variability. The obtained results showing the considerable recruitment of Bidens frondosa seedlings were confirmed by earlier research conducted by Gubertová et al. (2001). In light of performed studies it might be stated that successful seedling recruitment might influence on increase of number of individuals in natural conditions. Simultaneously, it should be added the observed decrease of number of Bidens frondosa individuals in shaded and partly shaded sites during last study season might be result of disturbance such as seasonal flooding. Such phenomenon was previously noted by Kasperek (2004).

The result of the research showing the occurrence of higher Bidens frondosa stems in sunny sites than in partly or completely shaded sites corresponds with experiments conducted in populations of closely related species - Bidens radiata and Bidens tripartita (Wisskirchen 2006). Individuals of the aforementioned species show a significant reduction in the height of stems as a result of a decrease in the period of light during the day. The increase of plant height in effect of augmentation of light availability was also recorded in Ammannia coccinnea (Gibson et al. 2001). In contrary, the decrease of stem length with increasing neighborhood density was found in Ambrosia artemisiifolia (Paquin \& Aarssen 2004).

On the basis of results of performed studies and published data (Graae 2002; Römermann et al. 2005), it can be concluded, that an increase in the stem length, fruit and seed production, as well as in seed dimensions and considerable seedling emergence enable persistence of Bidens frondosa population in open and sun-lit sites. Simultaneously, it should be add that a decrease in the height of the stems and achene size in partly-shaded and shaded places might contribute to long-distance dispersal of seeds by animals, while the substantial seedling recruitment allows to successful colonization of new areas.

\section{Acknowledgements}

The authors would like to thank to two anonymous reviewers for valuable suggestions enabling the great improvement of earlier version of manuscript. The authors are grateful to Prof. Dr hab. Helena Trzcińska-Tacik and Mgr. Stefan Gawroński for constructive suggestions and assistance in field work. The study was done within project N305 052434 financed by Ministry of Science and Higher Education in Poland.

\section{References}

Andrews M., Maule H.G., Hodge S., Cherrill A. \& Raven J.A. 2009. Seed dormancy, nitrogen nutrition and shade acclimation of Impatiens glandulifera: implications for successful invasion of deciduous woodland. Plant Ecol. Diversity 2: 145153.

Andrews M., Maule H.G., Raven J.A. \& Mistry A. 2005. Extension growth of Impatiens glandulifera at low irradiance: importance of $\frac{\text { nitrate and potassium accumulation. Ann. Bot. }}{\text { B. }}$ 95: 641-648.

Aule H. \& Brandl R. 1997. Seedling recruitment in the invasive clonal shrub, Mahonia aquifolium Pursh (Nutt.). Oecologia 110: 205-211.

Balogh L. 2008. Himalayan balsam (Impatiens glandulifera Royle), pp: 129-137. In: Botta-Dukát Z. \& Balogh L. (eds), The most important invasive plants in Hungary, Institute of Ecology and Botany, Hungarian Academy of. Sciences, Vácrátót, Hungary. 
Baumann D.T., Bastiaans L. \& Kropf M.J. 2001. Effects of intercropping on growth and reproductive capacity of lateemerging Senecio vulgaris L., with special reference to competition for light. Ann. Bot. 87: 209-217.

Bennington C.C. \& McGraw J.C. 1995. Natural selection and ecotypic differentiation in Impatiens pallida. Ecol. Monogr. 65: $303-324$

Berling D.J. \& Perrins J.M. 1993. Impatiens glandulifera Royle (Impatiens royleyi Walp.). J. Ecol. 81: 367-382.

Brown J.S. \& Eckert C.G. 2005. Evolutionary increase in sexual and clonal reproductive capacity during biological invasion in an aquatic plant Butomus umbellatus (Butomaceae). Am. J. Bot. 92: 495-502.

Chapman D.S. \& Gray A. 2012. Complex interactions between the wind and ballistic seed dispersal in Impatiens glandulifera (Royle). J.Ecol. 100: 874-883.

Chivinge O.A. \& Shweppenhauer M.A. 1995. Competition of soybean with blackjack (Bidens pilosa L.) and pigweed (Amaranthus hybridus L.). Afr. Crop Sci. J. 3: 73-82.

Cui Q-G. \& He W-M. 2009. Soil biota, but not soil nutrients, facilitate the invasion of Bidens pilosa relative to a native species Saussurea deltoidea. Weed Res. 49: 201-206.

Dietz H. \& Ullmann I. 1998. Ecological application of 'herbchronology': Comparative stand age structure analyses of the invasive plant Bunias orientalis L. Ann. Bot. 82: 471480.

Dietz H., Köhler A. \& Ullmann I. 2002. Regeneration growth of the invasive clonal forb Rorippa austriaca (Brasicaceae) in relation to fertilization and intraspecific competition. Plant Ecol. 158: 171-182.

Donohue K. \& Schmitt J. 1999. The genetic architecture of plas-

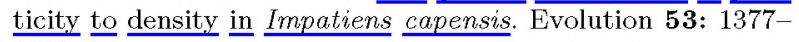
1386.

Dudley S.A. \& Schmidt J. 1995. Genetic differentiation in morphological responses to simulated foliage shade between populations of Impatiens capensis from open and woodland sites. Funct. Ecol. 9: 655-666.

Dudley S.A. \& Schmidt J. 1996. Testing the adaptive plasticity hypothesis: Density-dependent selection on manipulated stem length in Impatiens capensis. Amer. Nat. 147: 445-465.

Falińska K. 2002. Przewodnik do badań biologii populacji roślin. PWN, Warszawa, Poland, $586 \mathrm{pp}$.

Fitter A.H. \& Peat H.J. 1994. The Ecological Flora Database. J. Ecol. 82: 415-425.

Fumanal B., Chauvel B., Sabatier A. \& Bretagnolle F. 2007. Variability and cryptic heteromorphism of Ambrosia artemisiifolia seeds: What consequences for its invasion in France? Ann. Bot. 100: 305-313.

Fumanal B., Gaudota I. \& Bretagnolle F. 2008. Seed-bank dynamics in the invasive plant, Ambrosia artemisizfolia L. Seed Sci. Res. 18: 101-114.

Gibson K.D., Fischer A.J. \& Foin T.C. 2001. Shading and the growth and photosynthetic responses of Ammannia $\frac{\text { coccin- }}{\text { am }}$ nea. Weed Res. 41: 59-67.

Graae B.J. 2002. The role of epizoochorous seed dispersal of forest plant species in a fragmented landscape. Seed Sci. Res. 12: $113-121$

Gravuer K., von Wettberg E.J. \& Schmitt J. 2003. Dispersal biology of Liatris scariosa var. novae-angliae (Asteraceae), a rare New England grassland perennial. Am. J. Bot. 90: 11591167.

Gubertová H., Bendová K. \& Prah K. 2001. Seed ecology of alien Bidens frondosa in comparison with native species of the genus, pp: 99-104. In: Brundu G., Brock J., Camarda I., Child L. \& Wade M. (eds), Plant Invasions: Species Ecology and Ecosystem Management, Backhuys Publishers, Leiden, Netherlands.

Kasperek G. 2004. Fluctuations in numbers of neophytes, especially Impatiens glandulifera, in permanent plots in a west German floodplain during 13 years. Neobiota 3: 27-37.

Kollmann J., Bañuelos M.J. \& Nielsen S.L. 2007. Effects of virus infection on growth of the invasive alien Impatiens glandulifera. Preslia 79: 33-44.
Lambdon P.W., Pyšek P., Basnou C., Hejda M., Arianoutsou M., Essl F., Jarošík V., Pergl J., Winter M. Anastasiu P., Andriopoulos P., Bazos I., Brundu G., Celesti-Grapow L., Chassot P., Delipetrou P., Jossefson M., Kark S., Klotz S., Kokkoris Y., Kühn I., Marchante H., Perglová I. Pino J., Vilá Zikos A.., Roy D.B. \& Hulme P.E. 2008. Alien flora of Europe: species diversity, temporal trends, geographical patterns and research needs. Preslia 80: 101-149.

Lambrecht-McDowell S.C. \& Radosevich S.R. 2005. Population demographics and trade-offs to reproduction of an invasive and noninvasive species of $R$ ubus. Biol. Invas. $\overline{7}$ : $\overline{28} 1-295$.

Li W., Wang B. \& Wang J. 2006. Lack of genetic variation of an invasive clonal plant Eichhornia crassipes in China revealed by RAPD and ISSR markers. Aquatic Bot. 84: 176-180.

Maule H., Andrews M., Watson C. \& Cherrill A. 2000. Distribution, biomass and effect on native species of Impatiens glandulifera in a deciduous woodland in northeast England. Aspects Appl. Biol. 58: 31-38.

McGoey B.V. \& Stinchcombe J.R. 2009. Interspecific competition alters natural selection on shade avoidance phenotypes in Impatiens capensis. New Phytologist 183: 880-891.

Meyer S.E. 1997. Ecological correlates of achene mass variation in Chrysothamnus nauseosus (Asteraceae). Am. J. Bot. 84: $\overline{47} 1-477$.

Meyer S.E. \& Carlson L.S. 2001. Achene mass variation in Ericameria nauseosus (Asteraceae) in relation to dispersal ability and seedling fitness. Funct. Ecol. 15: 274-281.

Molina-Montenegro M.A., Badano E.I. \& Cavieres L.A. 2008. Positive interactions among plant species for pollinator service: assessing the 'magnet species' concept with invasive species. Oikos 117: 1833-1839.

Moravcová L., Pyšek P., Jarošík V., Havličková V. \& Zákravský P. 2010. Reproductive characteristics of neophytes in the Czech Republic: traits of invasive and non-invasive species. Preslia 82: 365-390.

Murphy G.P. \& Dudley S.A. 2009. Kin recognition: Competition and cooperation in Impatiens (Balsaminaceae). Am. J. Bot. 96: $1990-1996$.

Nienhuis C.M. \& Stout J.C. 2009. Effectiveness of native bumblebees as pollinators of the alin invasive plant Impatiens glandulifera (Balsaminaceae) in Ireland. J. Pollin. Ecol. 1: $1-11$.

Paquin V. \& Aarssen L.W. 2004. Allometric gender allocation in Ambrosia artemisiifolia (Asteraceae) has adaptive plasticity. Am. J. Bot. 91: 430-438.

Pergl J., Perglová I., Pyšek P. \& Dietz H. 2006. Population age structure and reproductive behavior of the monocarpic perennial Heracleum mantegazzianum (Apiaceae) in its native and invaded distribution ranges. Am. J. Bot. 93: 1018-1028.

Perglová I., Pergl J., Skálová H., Moravcová L., Jarošík V. \& Pyšek P. 2009. Differences in germination and seedling establishment of alien and native Impatiens species. Preslia 81: $357-357$.

Perrins J., Fitter A. \& Williamson M. 1993. Population biology and rates of invasion of three introduced Impatiens species in the British Isles. J. Biogeogr. 20: 33-44.

Piskorz R. 2005. The effect of oak-hornbeam diversity on flowering and fruiting of Impatiens parviflora. Rocz. AR. Pozn. CCCLXXIII Bot-Stec. 9: 187-196.

Prach K. 1994. Seasonal dynamics of Impatiens glandulifera in two riparian habitats in central England, pp. 127-133. In: de Waal LC (ed.) Ecology and Management of Invasive Reverside Plants, John Wiley Sohns, Chichester.

Prowse A. 1998. Patterns of early growth and mortality in Impatiens glandulifera, pp. 245-252. In: Starfinger U., Edwards K., Kowarik I. \& Williamson M. (eds), Plant Invasions: Ecological Mechanisms and Human Responses. Backhuys Publishers, Leiden, The Netherlands.

Pyšek P. \& Richardson D.M. 2010. Invasive species, environmental change and management, and health. Annu. Rev. Environ. Resour. 35: 25-55.

Riba M., Mignot M., Fréville H., Colas B., Imbert E., Vile D., Virevaire M. \& Olivieri I. 2005. Variation in dispersal traits in a narrow-endemic plant species, Centaurea corymbosa Pourret. (Asteraceae). Ecol. Evol. 19: 241-254. 
Riis T., Lambertini C., Olesen B., Clayton J.S., Brix H. \& Sorrell B.K. 2010. Invasion strategies in clonal aquatic plants: are phenotypic differences caused by phenotypic plasticity or local adaptation? Ann. Bot. 106: 813-822.

Rinella M.J., Masters R.A. \& Bellows S.E. 2010. Growth regulator herbicides prevent invasive annual grass seed production under field conditions. Rangeland Ecol. Manage. 63: 487-490.

Römermann C., Tackenberg O. \& Poschlod P. 2005. How to predict attachment potential of seeds to sheep and cattle coat from simple morphological seed traits. Oikos 110: 219-230.

Sakai A.K., Allendorf F.W., Holt J.S., Lodge D.M., Molofsky J., With K.A., Baughman S., Cabin R.J., Cohen J.E., Ellstrand N.C., McCauley D.E., O'Neil P., Parker I.M., Thompson J.N. \& Weller S.G. 2001. The population biology of invasive species. Ann. Rev. Ecol. Syst. 32: 305-332

Santalla E.M., Dosio G.A.A., Nolasco S.M. \& Aguirezzabál L.A.N. 2002. The effects of intercepted solar radiation on sunflower (Helianthus annuus L.) seed composition from different seed position. JAOCS 79:69-74

Schmidt J., Eccleston J. \& Ehrhardt D.W. 1987. Densitydependent flowering phenology, outcrossing, and reproduction in Impatiens capensis. Oecologia 72: 341-347.

Skálová H., Havličková V. \& Pyšek P. 2012. Seedling traits, plasticity and local differentiation as strategies of invasive species of Impatiens in Central Europe. Ann. Bot. 110: 1429-1438.

Skálová H., Jarošík V., Dvořáčková Š. \& Pyšek P. 2013. Effect of intra- and interspecific competition on the performance of native and invasive species of Impatiens under varying levels of shade and moisture. PLoS One. 8: e62842.

Strømme C.B. 2012. Quantity and quality of light affect growth and reproduction of the invasive annual plant Impatiens glandulifera. Norwegian University of Plant Sciences Department of Ecology and natural resource management, Master Thesis

Suzuki M., Kaya Y., Ishida T.A., Hattori K., Miki K., Nakamura T. \& Kiura M.T. 2007. Flowering phenology and survival of two annual plants Impatiens noli-tangere and Persicaria thunbergii co-occurring in streamside environments. Ecol. Res. 22: 496-501.

Toussaint B. \& Bedouet F. 2005. Les espčces végétales invasives des milieux aquatiques et humides du bassin Artois-Picardie. Agence de l'Eau Artois-Picardie, 38 pp. van Kleunen M. \& Johnson S.D. 2005. Testing for ecological and genetic Allee effects in the invasive shrub Senna didymobotrya (Fabaceae). Am. J. Bot. 92: 1124-1130.

Wang N., Yu F-H., Li P-X., He W-M., Liu F-H., Liu J-M. \& Dong M. 2008. Clonal integration affects growth, photosynthetic efficiency and biomass allocation, but not the competitive ability, of the alien invasive Alternanthera philoxeroides under severe stress. Ann Bot 101: 671-678.

Washitani I. \& Nishiyama S. 1992. Effects of seed size and seedling emergence time on the fitness components of $A m-$ brosia trifida and $A$. artemisiaefolia var. elatior in competition with grass perennials. Plant Spec. Biol. 7: 11-19.

Weing C., Gravuer K.A., Kane N.C. \& Schmitt J. 2004. Testing adaptive plasticity to UV: costs and benefits of stem elongation and light-induced phenolics. Evolution 58: $2645-2656$.

Vervoort A., Cawoy V. \& Jacquemart A.L. 2011. Comparative reproductive biology in co-occurring invasive and native $\mathrm{Im}$ patiens species. Int. J. Plant Sci. 172: 366-377.

Vilá M., Espinar J.L., Hejda M., Hulme P.E., Jarosik V., Maron J.L., Perl J., Schaffner U., Sun Y. \& Pyšek P. 2011. Ecological impacts of invasive alien plants: a meta-analysis of their effects on species, communities and ecosystems. Ecol. Lett. 14: 702-708

Willis S.G. \& Hulme P.E. 2004. Environmental severity and variation in the reproductive traits of Impatiens glandulifera. Funt. Ecol. 18: 887-898.

Wisskirchen R. 2006. An experimental study on the growth and flowering of riparian pioneer plants under long- and short-day conditions. Flora 201: 3-23.

Xiao Y., Junbing T., Hua Q., Changfang Z., Wijing K. \& Squging A. 2011. Trade-offs among growth, clonal, and sexual reproduction in an invasive plant Spartina alterniflora responding to inundation and clonal integration. Hydrobiologia 658: $353-363$.

Zollinger R.K. \& Kells J.J. 1991. Effect of soil pH, soil water, light intensity, and temperature on perennial sowhistle (Sonchus arvensis L.). Weed Sci. 39: 376-384.

Received June 5, 2013 Accepted November 22, 2013 